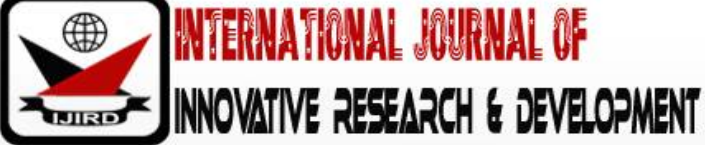

ISSN 2278 - 0211 (Online)

\section{The Impact of Emotional Intelligence on Job Performance: A Case of an International School in Nairobi, Kenya}

\author{
Joseph K Sambu \\ Ph.D. Student, Department of Leadership, PAC University, Kenya
}

\begin{abstract}
:
This study examined how emotional intelligence of teachers relates to their job performance and length of service in a selected international school within Nairobi city in Kenya. Correlational design and survey method were utilized. A purposive sampling technique was adopted where the 47 teachers in the school were given questionnaires in which they self-evaluated themselves on the two variables; emotional intelligence and job performance. The length of service of the teachers was extracted from records in the HR files. Microsoft Excel was used to generate constants for both descriptive statistics such as mean scores and standard deviations and inferential statistics which included; Pearson product moment correlation, Spearman rank, the Spearman's rho, and t values. The research found positive correlations between emotional intelligence, job performance and the length of service, hence emotional intelligence and the length of service can be used to predict job performance. Emotional intelligence theory and its applications can be adopted by international schools to promote managerial and human resource practices.
\end{abstract}

Keywords: Emotional intelligence, job performance

\section{Introduction and Background to the Study}

\subsection{Introduction}

Emotional Intelligence (EI) is the ability to reason about feelings that promote thinking. It incorporates the capacity to precisely see feelings, to get to and create feelings, to help thought, to get feelings and passionate learning, and to brilliantly control feelings in order to advance enthusiastic and intellectual development (Mayer, Salovey, \& Caruso 2004). To understand how such feelings may be controlled by teachers in schools, four indicators of EI were considered. These are Self-awareness, Emotional Management, Social Emotional Awareness, and Relationship Awareness. The studies done in Kenya have not addressed the relationship between EI and job performance (JP) of teachers working in an international school. The targeted international school follows the British curriculum which caters for children with different learning abilities, accommodates the huge cultural diversity in co-curricular activities, absorbs other educational systems and converts them into theirs.

\subsection{Background to the Study}

In an international school setup, students tend to display disruptive behavior in class which put teachers to test on emotional control. Teachers have heavy workloads and work in a hectic environment where the total balance of academic and co-curricular activities is done inside the week and notwithstanding amid the ends of the week. All these are done to offer the students a holistic education. To meet this objective, school administrators put a lot of pressure on the teachers where at times they become insensitive by not considering their ability, required skills and even the amount of time to complete the activities. Parents also come in with their demands which complicate the situation. Such scenarios which create psychological distress to the staff (Kokkinos, 2009 Malach-Pines, 2005: Skaalvik \& Skaalvic, 2007) require Emotional Intelligence to manage. This study investigated the level of emotional intelligence among the teaching staff of an international school in Nairobi Kenya and how it impacted on their job performance. The investigation established the relationship between emotional intelligence and work experience. The following objectives guided the investigations.

\subsection{Objectives}

- To assess the levels of EI of the teachers in a selected international school in Nairobi.

- To find out if there is any difference between EI of male and female teachers in the selected international school in Nairobi.

- To measure the level of job performance as perceived by the teachers of the selected international school in Nairobi

- To find out if any relationship existed between EI and the length of service of teachers in the selected international school in Nairobi. 
- To find out if any relationship existed between EI and job performance of teachers in the selected international school.

\subsection{Research Questions}

The research sought to answer the following questions:

- What are the levels of emotional intelligence among the teachers?

- What are the levels of job performance among the teachers?

- What is the relationship between the emotional intelligence of the teachers and their length of service?

- What is the relationship between the emotional intelligence of the teachers and their job performance?

\subsection{Hypotheses}

- $\mathrm{H}_{1}$ : There is no significant relationship between emotional intelligence and job performance of a teacher working in an international school setup.

- $\mathrm{H}_{2}$ : There is no difference between emotional intelligence of male and female teachers.

- $\mathrm{H}_{3}$ : There is no relationship between emotional intelligence and length of service of a teacher working in an international school.

\subsection{Assumptions of the Study}

The study assumed teachers gave their honest feedback to the questions asked in the questionnaires. It also assumed that the only variable moderating the relationship between emotional intelligence and job performance is the length of service of the teachers were kept constant.

\subsection{Justification, Rationale and the Significance of the Study}

Teachers resign and quit their jobs when they fail to cope with the levels of stress and some get fired by their employers. The relationship between EI and JP will help education planners and employers to come up with training programs equip teachers with EI skills. The skills acquired help them to cope with the levels of stress and increase their chances of employability and performance. Scullen, Mount, and Goff (2000) stated that job performance acts as an important concept in organizational practice and research. The results from this study can be used by international schools in decision making since work performance often depends on the support, advice, and other resources provided either in person or from the literature review (Seibert, Kraimer \& Liden, 2001). Furthermore, if a positive relationship between Emotional Intelligence and work experience is established, then the board of management may use the recommendations to devise methods of retaining the teachers for a long period of time. Otherwise, if the contrary is found, the board will have no choice other than to invest in staff development initiatives to enhance several constructs like Emotional Intelligence which have been known to improve job performance.

\section{Review of Related Literature}

\subsection{Introduction}

This chapter defines EI, JP and describes their indicators in the international school context. The relationship between EI and JP is described in a theoretical framework adopted from Goleman (2001). Emotional Intelligence (EI) is understood from its components which are enlisted as; Self-awareness, self-regulation, social emotional awareness, and relationship awareness.

\subsection{Self - Awareness}

Grayson (2013) characterizes self-awareness as the capacity to perceive one's sentiments, to separate between them, to comprehend what one is feeling and why, and to recognize what caused the emotions. Then again, Goleman (1998) sees passionate self-awareness as a method for distinguishing an individual's feeling and its belongings. Selfawareness is the most urgent competency related to workplace emotional intelligence. Yeung (2009) expressed that the initial step of ending up sincerely shrewd is to progress toward becoming as self-aware as could be expected under the circumstances. Yeung contends that if emotional intelligence was a voyage, at that point self-awareness would be the ability to guide the journey.

\subsection{Self - Regulation}

Emotional management or self-regulation or self-management is the second of Goleman's core competencies considered in this study. Emotional management is the ability to remain calm during provocative or conflict situation, while keeping defensiveness to a minimum and ultimately renovating rationality (Wolmarans \& Martins, 2001). Selfregulation progresses primarily from social source and changes to individual sources in a sequence of levels (Schunk \&Zimmerman, 2003). According to Schunk and Zimmerman (2003), self-regulation would encourage people to take amore powerful role on their thoughts, emotions, and performances.

\subsection{Social Emotional Awareness}

Goleman (2001) characterizes Social emotional awareness as the capacity to comprehend and react to the necessities of others and imprints it as the third area of emotional intelligence. Goleman recognized the capabilities related with Social emotional awareness as: Empathy which is understanding the other individual's feelings, needs and concerns, 
organizational awareness which is the ability to understand the politics within an organization and how these affect the people working in them, administration which is the capacity to comprehend and address the issues of customers and clients, attention to social circumstances meaning you cautiously think about what individuals need, and plan to speak with them in a manner that is expected to address that issue. Goleman noticed that digital communication, social networking, video conferencing and other forms of new media have contributed to social isolation which are frequently accused for the decrease in compassion.

\subsection{Social Emotional Awareness}

Social aptitudes allude to an individual's ability in overseeing association with others and building frameworks additionally called relationship building abilities. The arrangement of social abilities incorporates regard for other people, shared respect, duty, receptiveness, resistance, sympathy, exchange, correspondence and so forth (Schuetz, 2011). It includes the capacity of gathering each other's needs, identifying with one another after some time and trading data around one inclination, thought and thoughts. Different characteristics, social abilities are successful in driving change, inducing others, building and driving groups (Goleman 1995). Social collaboration additionally results in numerous focal points. It gives certainty and social acknowledgment. It can help directors from numerous points of view. It can help do numerous things which can't be finished alone, for instance; getting support from a group or finishing a venture (Pettry, 2006).

\subsection{Job Performance}

Job performance (JP) refers to "the total expected value to the organization of the discrete behavioural episodes that an individual carries out over a standard period. Other than that, it is also an individual output in terms of quality and quantity expected from every employee in a job. This shows that an individual performance is most of the time determined by motivation and the will and ability to do the job. " (Motowildlo, 2003, p. 42). JP in the present study is measured using Tseng and Huang's (2011) six-item scale which is based on Katz and Kahn's conceptualization of the construct in terms of in-role and extra-role behavior in accordance with the Role Behavior Theory. In their model, in-role behavior is "behavior that falls under standard rules in the workplace of an organization," and extra-role behavior represents "the selfevaluative and democratic behavior that is accepted within the organization" (Tseng \& Huang, 2011, p. 6119). Job performance (JP) alludes to the absolute anticipated value to the organization of the discrete conduct scenes that an individual does over a standard timeframe. Other than that, it is likewise an individual yield regarding quality and amount anticipated from each worker in specific employment. This demonstrates an individual execution is more often than not controlled by inspiration and the will and capacity to carry out the responsibility (Motowildlo, 2003, p. 42). JP in the present study is estimated utilizing Tseng and Huang's (2011) six-item scale which depends on Katz and Kahn's conceptualization of the development as far as in-job and additional job conduct as per the Role Behavior Theory. In their model, in-job conduct is conduct that falls under standard principles in the work environment of an organization, and additional job conduct speaks to the self-evaluative and popularity-based conduct that is acknowledged inside the organization (Tseng and Huang, 2011, p. 6119).

\subsection{Emotional Intelligence and Job Performance}

Several studies investigating the relationship between emotional intelligence and job performance have been conducted outside Kenya and not much if any within the country. Those already conducted (not in a school situation) revealed that emotional intelligence contributes significantly to success in job performance. Cavallo and Brienza (2002) contributed in this field where they found that the high performers had significantly more emotional competencies than did low performers. In education, Lyons and Schneider (2005) examined the relationship of ability based emotional intelligence facets with performance under stress. The findings indicated that certain dimensions of emotional intelligence were related to more challenge and enhanced performance. Some studies have shown that emotional intelligence is important in a wide range of settings, including education and business and is related to achievement, productivity, leadership, personal health and job performance. Carmeli (2003) found that employees with a high level of intelligence can manage their emotions in terms of retaining a positive mental state which can lead to improved job performance. EI in the field of education has been found to improve performance (Arnold, 2005; Jennings \& Greenberg, 2009; Rohana, Kamaruzaman, \& Zanariah, 2009; Sutton, 2004; Najmuddin, Noriah, \& Mohamad, 2011). In addition, it has been found that Emotional Intelligence contributes positively towards the teaching role (Corcoran \& Tormey, 2012). Cote and Miners (2006) examined the relationship between emotional intelligence, intelligent quotient and job performance and found that intelligence quotient moderated the association between emotional intelligence and job performance. This study investigated the relationship between emotional intelligence and job performance in an international context.

\subsection{Theoretical Framework}

The theoretical framework of the study is illustrated in the framework (see Figure 1). It is believed that if a significant positive relationship between Emotional Intelligence is found, a moderator is introduced to enhance the dimensions of emotional intelligence, consequently leading to increased job performance. 


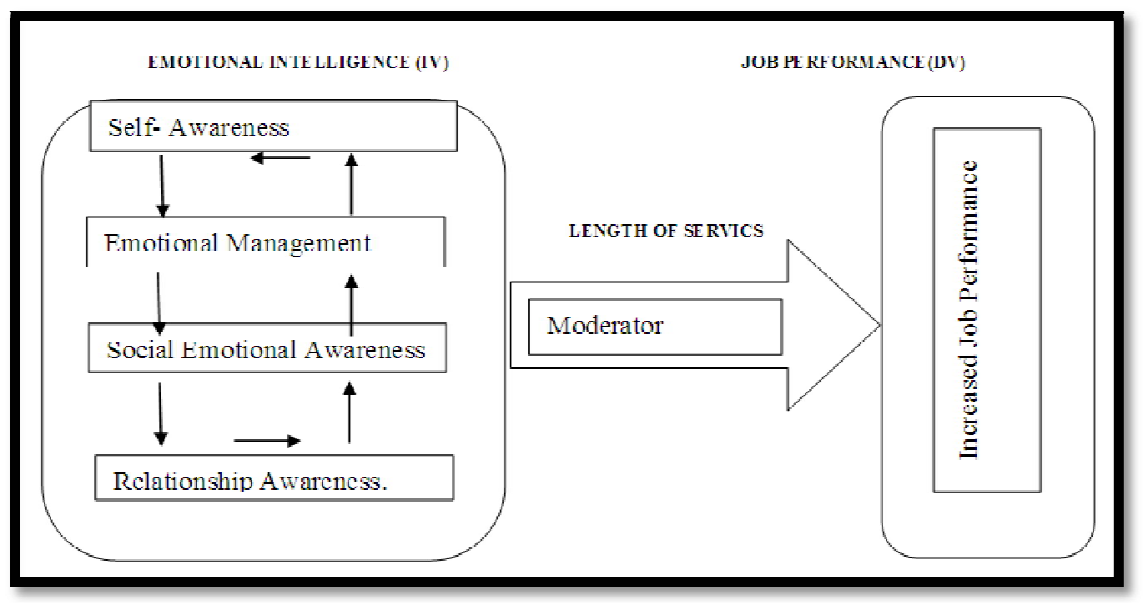

Figure 1: Theoretical Research Framework

Source: Goleman (2001)

\section{Research Methodology}

\subsection{Introduction}

In this study, the four dimensions were measured to determine the level of emotional intelligence of teachers. Other factors related to their job were also measured to give the overall value of job performance. Measuring was done through self-rating where each participant was given the opportunity to rate their respective levels of emotional intelligence using the four indicators and the tasks and job performance based on the list of tasks in the job performance questionnaire.

\subsection{Research Design}

This study adopted a correlational research design proposed by Welch (1974) who defined correlation as a statistical test to establish patterns for two variables. Correlational design establishes whether two or more variables are related (Bold, 2001). The two variables used in the study were Emotional Intelligence (EI), and Job Performance (JP). EI was used as an independent variable to predict the outcome JP under the moderation of the Length of Service (LOS). The variables were measured and examined to find if they were related within an international school setup.

\subsection{The Population}

The study investigated the relationship between emotional intelligence and job performance among the 47 members of teaching staff selected from the primary and secondary sections of one of the international schools in Nairobi Kenya.

\subsection{The Sample Size and Sampling Procedure}

Purposive sampling was used where all the 47 teachers were taken as respondents. The distribution of the age of both male and female teachers is shown in Table 1.

\begin{tabular}{|cccccc|}
\hline $\begin{array}{c}\text { Age } \\
\text { (Years) }\end{array}$ & Total & Male & $\%$ & Female & $\%$ \\
\hline \hline Under 26 & 0 & 0 & 0.0 & 0 & 0 \\
$26-29$ & 1 & 0 & 0.0 & 1 & 2.1 \\
$30-34$ & 11 & 2 & 4.3 & 9 & 19.1 \\
$35-39$ & 14 & 6 & 12.8 & 8 & 17.0 \\
$40-44$ & 7 & 3 & 6.4 & 4 & 8.5 \\
$45-49$ & 7 & 4 & 8.5 & 3 & 6.4 \\
Above 49 & 6 & 3 & 6.4 & 4 & 8.5 \\
\hline
\end{tabular}

Table 1: The Distribution of Age of Male and Female Teachers Source: School HR Records, 2016 


\subsection{The Instrument}

Data was collected using a questionnaire which was developed and adapted from International Institute for Educational Planning (UNESCO, 2005; MESA, 2014; Goodman \& Svyantek, 1999). The questionnaire consists of 3 parts, which are part 1, part 2(A) and part 2(B). Part 1 contains questions distributed equally between the four indicators of EI listed as: Self-Awareness, Emotional Management, Social Awareness and Relationship Awareness. Part 2(A) contains questions associated with job performance in form of contextual and task performance (Goodman \& Svyantek, 1999) while part 2(B) consists of questions on demographics (Age, Sex and Length of Service) of the respondents (see the research instruments in the Appendices). For the first variable (Emotional Intelligence), forty items were used while the second variable (Job Performance) had sixteen items. For each item a corresponding Likert scale was provided where a respondent was expected to rate their level of practice regarding EI or JP as follows: 0 (Never), 1 (Rarely), 2 (Sometimes), 3 (Often) and 4 (Always).

\subsection{Analysis Procedures}

Descriptive and inferential statistical procedures were used to analyze the data. Descriptive statistics such as means, percentages and standard deviations, were used to describe sample characteristics and presented in tables and figures. For inferential statistics, t-test, Spearman rank and Pearson moment correlation coefficient were used in data analysis. To check the reliability of the instrument, 6 members of teaching staff selected from a nearby international school filled the questionnaires for the pilot study and returned for scoring. Analysis of the questionnaires for the pilot study was done utilizing the techniques proposed by (Norland, 1990) and split - half reliability Spearman Brown formula (Korb, 2016) which is applicable to Likert scale questionnaires. The results from the pilot study showed that the instrument was reliable (see Table 2). Reliability refers to the degree of consistency or accuracy with which an instrument measures the attribute it has been designed to measure (Polit \& Hungler, 2013).

\begin{tabular}{|c|c|c|c|c|c|c|}
\hline Respondent & $\begin{array}{c}\text { EI Average } \\
\text { score (Max =40) }\end{array}$ & Rank & $\begin{array}{c}\text { Job } \\
\text { Performance } \\
\text { Total (Max=64) }\end{array}$ & Rank & Deviating(d) & $\mathbf{d}^{\mathbf{2}}$ \\
\hline 1 & 30 & 4 & 53 & 4 & 0 & 0 \\
\hline 2 & 29 & 5 & 54 & 3 & 2 & 4 \\
\hline 3 & 35 & 2 & 58 & 2 & 0 & 0 \\
\hline 4 & 32 & 3 & 51 & 5 & -2 & 4 \\
\hline 5 & 28 & 6 & 48 & 6 & 0 & 0 \\
\hline 6 & 36 & 1 & 59 & 1 & 0 & 0 \\
\hline & & & & & $\Sigma \mathrm{d}^{2}=$ & 8 \\
\hline
\end{tabular}

Table 2: Reliability Test for Research Questionnaires

The spearman rho (r)

$\begin{array}{llll}= & 1 & - & 6 \times\left(\mathrm{d}^{2}\right) / \mathrm{n}\left(\mathrm{n}^{2}-1\right) \\ = & 1 & - & 6 \times 8 / 6(36-1) \\ = & 1 & - & 48 \times(6 \times 35) \\ = & 1 & - & 48 / 210 \\ = & 1 & - & 0.229 \\ = & 0.771 & & \end{array}$

The Spearman Brown reliability constant of the pilot test of research questionnaires

$\begin{array}{rll}\alpha & = & (2 \times \mathrm{r}) /(1+\mathrm{r}) \\ & = & 1.543 / 1.771 \\ & = & 0.871\end{array}$

Generally, a questionnaire with an $\alpha$ greater than 0.6 is considered reliable (Field, 2009). After certifying internal consistency, the questionnaires were administered to the 47 respondents who filled and returned them to the researcher for analysis. Ethical standards were observed. The consent of the participants was sought before engaging them in the research and they were asked to participate at their convenient time (Hennink, Hutter, \& Bailey, 2010). The participants were assured that the information revealed would be used for research purposes only and treated with confidentiality. The questionnaires were analysed using Microsoft Excel and the results were presented using tables.

\section{Results}

\subsection{Introduction}

The four indicators; self-awareness, emotional management, social emotional awareness, and relationship awareness were measured to determine the level of emotional intelligence of teachers. Other factors related to their job were also measured to give the overall value of job performance. Each participant was given the opportunity to rate their respective levels of performance in EI and JP.

\subsection{Demographics of the Sample by Gender and Age}

The teachers were asked to indicate their gender and age in the second part of the questionnaire. The results are shown in Table 3 below. 


\begin{tabular}{|c|c|c|c|c|c|}
\hline Age (Years) & Total & Male & \% & Female & \% \\
\hline Under 26 & 0 & 0 & 0.0 & 0 & 0 \\
\hline $26-29$ & 1 & 0 & 0.0 & 1 & 2.1 \\
\hline $30-34$ & 11 & 2 & 4.3 & 9 & 19.1 \\
\hline $35-39$ & 14 & 6 & 12.8 & 8 & 17.0 \\
\hline $40-44$ & 7 & 3 & 6.4 & 4 & 8.5 \\
\hline $45-49$ & 7 & 4 & 8.5 & 3 & 6.4 \\
\hline Above 49 & 6 & 3 & 6.4 & 4 & 8.5 \\
\hline Total & 47 & 18 & 38.3 & 29 & 61.7 \\
\hline
\end{tabular}

Table 3: Staff Age Distribution by Gender

The participants under this study were made up of 29 (61.7\%) females and 18 (38.3\%) males. The higher number of females in the study compared to males reflected the staffing situation in the school, where there are generally more female teachers than male teachers. This scenario may be attributed to the fact that male teachers may be changing their careers after some time. The figures from the table also indicates that 25 teachers were between 30 and 39 years of age representing (53.2\%). This is a very productive age group with at least ten years of working experience. The other information retrieved from the teachers' appraisals was the length of service or years of experience in the teaching profession. The distribution of the length of service of teachers is summarized in Table 3.

\begin{tabular}{|c|c|c|c|c|c|}
\hline Length of Service & Total & Male & $\mathbf{\%}$ & Female & \% \\
\hline Under 5 & 4 & 2 & 4.3 & 2 & 4.3 \\
\hline $5-9$ & 12 & 4 & 8.5 & 8 & 17.0 \\
\hline $10-14$ & 16 & 4 & 8.5 & 12 & 25.5 \\
\hline $15-19$ & 6 & 5 & 10.6 & 1 & 2.1 \\
\hline $20-24$ & 3 & 2 & 4.3 & 1 & 2.1 \\
\hline $25-29$ & 1 & 0 & 0.0 & 1 & 2.1 \\
\hline Above 29 & 5 & 3 & 6.4 & 2 & 4.3 \\
\hline Total & 47 & 20 & 42.6 & 27 & 57.4 \\
\hline
\end{tabular}

Table 4: Distribution of Staff Length of Service per Gender in Years

The results indicated that 26 (55.3\%) of the teachers had served in the school for between 5 and 14 years. Very few teachers were employed directly after college because among the requirements for recruitment in the school was at least 3 years of teaching experience in an international school. After gaining good experience of over 10 years, the teachers become marketable and move to other international schools offering better pay. A total of 15 teachers were in this group constituting (31.9\%). The smaller number of teachers recruited with experience below the required 3 years got their employment because of emergency reasons. Emergency situations arise when one or two teachers either get greener pastures in teaching, change careers or resigned for some reasons. Fresh graduates from college are given the opportunity to learn on the job while covering the lessons left by those leaving for the supposed reasons.

- Research question 1 , The research sought to answer the following question:

What are the levels of emotional intelligence among the teachers? The questionnaires were collected, analysed and the results are shown in table 5 .

\begin{tabular}{|c|c|c|c|}
\hline Gender & $\mathbf{n}$ & $\begin{array}{c}\text { Mean (\%) } \\
\text { (Max score = 40) }\end{array}$ & Std \\
\hline Male & 18 & $29.9(74.7 \%)$ & 2.98 \\
\hline Female & 29 & $28.6(71.6 \%)$ & 2.31 \\
\hline Total & 47 & $29.1(72.7 \%)$ & 2.49 \\
\hline
\end{tabular}

Table 5: The Levels of Emotional Intelligence among Male and Female Staff (Self-Rating)

Emotional Intelligence variable consisted of four indicators for instance; self-awareness, self-management, social awareness and relationship management. The average of all the four indicators was calculated out of 40 and converted to percentage. From the figures in Table 4, female teachers rated themselves slightly lower at (71.6\%) than male teachers who rated themselves at $74.7 \%$. The average rating for the study group was $72.7 \%$. Data on the levels of emotional intelligence was also analysed using the standard deviation. The small values of 2.31 and 2.98 in standard deviation among female and male teachers respectively showed that their levels of emotional intelligence varied with small margins from the mean.

- Research question 2. What are the levels of job performance among the teachers?

The questionnaires were analysed to establish the levels of job performance among the teaching staff. The results are summarized in table 6. 


\begin{tabular}{|c|c|c|c|}
\hline Gender & $\mathbf{n}$ & $\begin{array}{c}\text { Mean } \\
\text { (Expected score } \mathbf{6 4 )}\end{array}$ & Std \\
\hline Male & 18 & $30.4(47.5 \%)$ & 3.06 \\
\hline Female & 29 & $31.1(47.7 \%)$ & 1.88 \\
\hline Total & 47 & $30.8(47.8 \%)$ & 2.42 \\
\hline
\end{tabular}

Table 6: The Levels of Job performance Among Male and Female Staff (Self-Rating)

The job performance variable incorporated performance factors such as innovation, competence, achievement of objectives, planning, organizing and responsibility among others. The total of all the factors was calculated out of 64 and converted to percentage. From the figures in the table, female and male teachers rated themselves equally at (48\%) which gave the same average for the whole group. Data on the levels of job performance was also analysed using the standard deviation. The female standard deviation of 1.88 was found to be lower than that of male teachers at 3.06. This difference could be attributed to the fact that female teachers like sharing and discussing several issues in groups hence there is a likelihood that they benchmarked their performance against each other. On the other hand, male teachers like working independently and each one minding their own business hence a slight variation in their performance.

Research question 3.

What is the relationship between the emotional intelligence of the teachers and their job performance? The mean scores of the two variables i.e. emotional Intelligence and job performance were investigated to find out if any relationship existed between them. The elements of Pearson product moment correlation were computed using Microsoft excel 2016 and the results were summarized in Table 6 .

\begin{tabular}{|c|c|c|c|c|c|}
\hline Gender & $\begin{array}{c}\text { EI Mean Scores (\%) } \\
\text { (X) }\end{array}$ & $\begin{array}{c}\text { JP Mean Scores } \\
\text { (\%) (Y) }\end{array}$ & X2 & Y2 & XY \\
\hline Male $(\mathrm{n}=18)$ & 74.7 & 47.5 & & & \\
\hline Female(n=29) & 71.6 & 47.7 & & & \\
\hline Sum (N=47) & 3523 & 2261 & 2657 & 109421 & 170301 \\
& $\overline{\mathrm{X}}=72.8$ & $\overline{\mathbf{Y}}=47.6$ & 81 & & \\
\hline
\end{tabular}

Table 7: The Correlation Coefficient between Emotional Intelligence and Job Performance

To find the exact value of this correlation, Pearson product moment correlation was calculated. Each of the sums in Table 6 was substituted into the raw score formula where the correlation coefficient was calculated as follows: -

$$
\begin{aligned}
& \mathrm{r}=\frac{\mathrm{N} \sum \mathrm{XY}-\left(\sum \mathrm{X}\right)\left(\sum \mathrm{Y}\right)}{\sqrt{\mathrm{N} \sum \mathrm{X}^{2}-\left(\sum \mathrm{X}\right)^{2}} \sqrt{\mathrm{N} \sum \mathrm{Y}^{2}-\left(\sum \mathrm{Y}\right)^{2}}} \\
& =(47 \mathrm{x} 265781)-(3523 \mathrm{x} 2261) / \sqrt{ }(47 \mathrm{x} 265781-35232) \mathrm{x} \sqrt{ }\left(47 \times 109421-2261^{2}\right) \\
& =(12491707-7965503) / \sqrt{ }((80178) \times(175.12)) \\
& =39984.38 / 50914.71 \\
& \quad=0.785
\end{aligned}
$$

This value showed a positive relationship between emotional intelligence and job performance.

\subsection{Testing of Hypotheses}

The first hypothesis was stated as:

$\mathrm{H}_{01}$ : There is no significant relationship between emotional intelligence and job performance of a teacher working in an international school setup.

Emotional intelligence showed a positive correlation with job performance $(r=0.785)$, but how significant is this relationship? To answer this question, Welch's t-test (Welch, 1974) was used to investigate if the change in mean scores was significant. The null hypothesis was tested at the 0.05 level of significance ( $95 \%$ confidence level). The null hypothesis is normally rejected if the calculated value of $t$ is greater than the critical value $t_{c}=1.96$ and accepted if it is lower than tc (Kothari, 2004). The t statistic was calculated as follows:

$$
t=\frac{\bar{X}_{1}-\bar{X}_{2}}{s_{\bar{X}_{1}-\bar{X}_{2}}}
$$

Where

$$
\begin{array}{lll}
\mathrm{s}_{1}{ }_{1} & = & \text { Variance of emotional intelligence scores }=(2.49) \\
\mathrm{s}_{2} & = & \text { Variance of job performane scores }=(2.42) \\
\mathrm{n}_{1} & = & \text { The number of respondents in Emotional Intelligence questionnaire }=(47) \\
\mathrm{n}_{2} & = & \text { The number of respondents in job performance questionnaire }=(47)
\end{array}
$$

Degrees of freedom $\quad(\mathrm{Df})=\mathrm{n}_{1}+\mathrm{n}_{2}-2$ (Kothari, 2004)

$=\quad 47+47-2$

$=92$


And

$$
\begin{aligned}
& s \bar{X}_{1}-\bar{X}_{2}=\sqrt{\frac{s_{1}^{2}}{n_{1}}+\frac{s_{2}^{2}}{n_{2}}} \quad \text { (Kothari, 2004) } \\
& =\sqrt{\frac{2.49+2.42}{47}} \\
& =\sqrt{\frac{4.91}{47}} \\
& =0.3232 \\
& \begin{array}{cll}
\text { Hence } \mathrm{t} & = & (72.8-47.6) / 0.3232 \\
= & 78.0 &
\end{array}
\end{aligned}
$$

Since $t>t_{c}$, the null hypothesis is rejected while the alternative one is adopted and re-stated as:

- $\mathrm{Ha}_{1}$ : There is a significant relationship between emotional intelligence and job performance of a teacher working in an international school setup.

Similar treatments were applied to the second and the third hypotheses where the t values were 0.83 and 94 respectively. Hypothesis (ii) was stated as:

- $\mathrm{H}_{02}$ : There is no difference between emotional intelligence of male and female teachers.

Since $t<t_{c}$, the null hypothesis was accepted hence emotional intelligence of male and female teachers was the same. For the third hypothesis stated as:

- $\mathrm{H}_{03}$ : There is no relationship between emotional intelligence and length of service of a teacher working in an international school, $t>t_{c}$ hence the null hypothesis was rejected. The alternative hypothesis was taken stated as:

- $\mathrm{Ha}_{3}$ : There is a significant relationship between emotional intelligence and the length of service of a teacher working in an international school setup.

\section{Discussion, Recommendations and Conclusion}

\subsection{Introduction}

The level of performance of emotional intelligence was found to be higher than that of job performance. The high level of Emotional Intelligence is attributed to numerous staff insets organized by the school over the years to train the staff on topics like stress management, how to deal with emotions, life-work balance among other topics which are highly related to emotional intelligence.

\subsection{Relationship between Emotional Intelligence and Job Performance}

This study investigated the relationship between Emotional intelligence and job performance. The impact of emotional intelligence on job performance was found to be significant. This in other words suggests that Emotional intelligence significantly and directly predicts Job Performance. It indicates that increased Emotional Intelligence is associated with higher job performance which agrees with past research (Shooshtarian et al., 2013) where employees with higher level of emotional intelligence demonstrated a higher level of job performance. This revelation is important to the school and the HR department in particular. The HR panel can use this information to design interview documents that capture emotional intelligence of the interviewees so that after the interview, the right candidates are recruited with a higher probability of good performance (Mayer \& Salovey, 1999). Mayer and Salovey (2000) suggested that high emotional intelligence contributes to high performance because emotional intelligence enables people to nurture positive relationships at work, work effectively in teams, and build social capital. They observed that job performance often depends on the support, advice and other resources provided. From this study, the high level of emotional intelligence was attributed to the numerous staff insets organized over the years by the school. One of the seminars organized within the academic year in the school was to equip the staff with the knowledge on how to cope with stress at work. Another important topic covered was dealing with emotions. This was organized because some students in the school had come to pursue their talents in sports and music and were not putting in enough energy to improve their academic performance. During lesson time, the students were exhibiting forms of disruptive behaviour which was putting the staff in emotive positions. In an isolated case, a member of staff was not able to control own anger and slapped a student which the management interpreted as corporal punishment. This form of punishment is unacceptable in any school in Kenya and if a teacher commits it, disciplinary procedures may be initiated which may result in dismissed from employment. The seminars on how to manage emotions that the school organized assisted a great deal as shown by the high rating the staff gave themselves on emotional intelligence. Emotional intelligence enables people to better regulate their emotions and perform more effectively under pressure and to cope with changes in a given organization. In summary, knowing that employees who are more capable of managing and regulating how they feel influences how they perform and accomplish their duties and tasks. This has useful implications.

\subsubsection{Recommendations and Implications}

The findings of the present study that emotional intelligence improves job performance agrees with the results of the study done earlier by Mayer et al. (2000). Investing in initiatives to build emotional intelligence can greatly affect organizational behavior and consequently affect performance. The effectiveness and efficiency of the organization in reaching its goals depend on the how employees perform their duties. A measure of how schools meet their objectives 
dictates the level at which they will attract new students and staff which in turn is directly linked with the profit margins. On the other hand, the longer a teacher stays within the organization, the more experience they gain hence better performance as shown by the results of the study. The findings depended on the assumptions stated earlier. There were limitations which can be addressed in future research.

\subsubsection{Limitations and Future Research}

One limitation of the current study lay in the measurement of emotional intelligence and job performance which relied on self-rating by the teachers. Future research may focus on exploring the relationships based on ratings done by an independent participant like the quality assurance officers from the ministry of education. Another limitation lies in the data which was a bit limited since they were obtained from one school. The same study may be conducted using a bigger sample involving several international schools to improve on its credibility. Also, holding other moderation factors like educational qualifications was limiting. Further study incorporation more moderating factors would enrich the findings.

\subsection{Conclusion}

Teachers play important leadership roles as far as students are concerned hence the more they gain more knowledge and develop high levels of emotional intelligence, the more they perform their roles and improve the overall performance of the school. The ability to deal with emotions is very important for lenders (Clutterbuck \& Megginson, 1999).

\section{References}

i. Arnold, R. (2005). Emphatic intelligence: Teaching, learning and relating. Sydney: UNSW Press.

ii. Carmeli, A. (2003). The relationship between emotional intelligence and work attitudes, behavior, and outcomes: An examination among senior managers. Journal of Managerial Psychology, 18(8), 788-813.

iii. Cavallo, K. Brienza, D. (2002). Emotional competence and leadership excellence at Johnson \& Johnson: The emotional intelligence and leadership study. Retrieved from: http:/ / www.eiconsortium.org/ research/jj_ei_study.htm.

iv. Cherniss, C. \& Goleman, D. (1998). Bringing emotional intelligence into the workplace: A technical report issued by the consortium for research on emotional intelligence in organizations. Boston: Hay/ McBer Group.

v. Clutterbuck, D., \& Megginson, M. (1999). Mentoring executives and director. Oxford: Blackwell.

vi. Corcoran, R. P., Tormey, R. (2012). How emotionally intelligent are pre-service teachers? Teaching and Teacher Education, 28, 750-759.

vii. Field, A. (2000). Discovering statistics using SPSS for Windows. Sage: London.

viii. Foote, D. (2001). What's your 'emotional intelligence? Computerworld, 35(7), 28.

ix. Fried, Y., \& Ferris, G. R. (1987). The validity of the job characteristics model: A review and meta-analysis. Personnel Psychology, 40(2), 287-322.

x. Goleman, D. (1995). Emotional intelligence. New York: Bantam Books.

xi. Goleman, D. (1998). The Emotionally intelligent workplace: An EI-Based Theory of Performance. In Cherniss C. \& Goleman D. (Ed). Consortium for Research on Emotional Intelligence in Organizations.

xii. Goleman, D. (2005). Emotional intelligence. U.S.A: Bentam book.

xiii. Goleman, D., Boyatzis, R. \& McKee, A. (2001). Primal leadership: The hidden driver of great performance. Harvard Business Review , 42- 51.

xiv. Goodman, S. A., \& Svyantek, D. J. (1999). Person-organization fit and contextual performance: Do shared values matter. Journal of Vocational Behavior, 55(2), 254-275.

xv. Grayson, R. (n.d.). Emotional Intelligence: A Summary. Retrieved from http:/ / www.visionrealization.com

xvi. Kokkinos, C. M. (2007). Job stressors, personality and burnout in primary school teachers. British Journal of Educational Psychology, 77, 229-243.

xvii. Kothari, C.R. (2004). Research methodology. Methods and techniques (2nd ed.). New Delhi: New Age International.

xviii. Lyons, J. B. \& Schneider, T. R. (2005). The influence of emotional intelligence on performance. Personality and Individual Differences, 39, 693-703.

xix. Malach-Pines. (2005). The Burnout Measure, short version. International Journal of Stress Management, 12, 7888.

xx. Mayer, J. D., \& Ciarrochi, J. (2006). Clarifying concepts related to emotional intelligence: A proposed glossary, emotional intelligence in everyday life (2nd ed.). New York: Psychological Press.

xxi. Mayer, J. D., \& Salovey, P. (1990). Emotional intelligence, imagination, cognition, and personality. Cognition and Personality, 9, 185-211.

xxii. Mayer, J. D., \& Salovey, P. (1997). What is emotional intelligence? Emotional Development and Emotional Intelligence: Implications for Educators. New York: Basic Books.10

xxiii. Mayer, J. D., DiPaolo, M. T., \& Salovey, P. (1990). Perceiving affective content in ambiguous visual stimuli: A component of emotional intelligence. Journal of Personality Assessment, 54, 772-781.

xxiv. Mayer, J. D., Salovey, P., \& Caruso, D. R. (2004). Emotional intelligence: theory, findings, and implications. Psychological Inquiry, 15(3), 197-215.

xxv. Mayer, J. D., Salovey, P., Caruso, D. R. (2000). Models of emotional intelligence. In R. Sternberg (Ed.), Handbook of intelligence. Cambridge: Cambridge University Press. 
xxvi. Mayer, J., Salovey, P., \& Caruso, D. (2008). Emotional intelligence new ability or eclectic traits? American Psychologist, 63(6), 503-517.

xxvii. Meisler, G., \& Vigoda-Gadot, E. (2010). Emotions in management and the management of emotions: The impact of emotional intelligence and organizational politics on public sector employees. Public Administration Review, 70(1), 72-86.

xxviii. MESA. (2014). The quick emotional intelligence self- assessment. Retrieved from https:/ / www.sdcity.edu/ Portals/ 0/ CMS_Editors/ MESA/ PDFs/ EmotionalIntelligence.pdf

xxix. Motowildlo, S. J. (2003). Job Performance. In: Borman, W. C., \& Ilgen, D. R, \& Klimoski, R. J. (Ed), Handbook of Psychology pp. 39-54. Hoboken, New Jersy: John Wiley \& Sons. Inc

xxx. Najmuddin, S. H. S., Noriah, M. I., Mohamad, B. (2011). Impacts of emotional intelligence on work values of high school teachers. Procedia Social and Behavioral Sciences, 30, 1688-1692.

xxxi. Norland-Tilburg, E. V. (1990). Controlling error in evaluation instruments. Journal of Extension, 28(2). Available at http:/ / www.joe.org/ joe/ 1990summer/ tt2.html

xxxii. Pettry, DW. (2006). Building social skills through activities, certified therapeutic recreation specialist.

xxxiii. Polit, D.F., \& Hungler, B.P. (2013). Essentials of nursing research: methods, appraisal, and utilization (8th Edition Ed.). Philadelphia: Wolters Kluwer/ Lippincott Williams and Wilkins.

xxxiv. Rohana, N., Kamaruzaman, J., Zanariah, A. R. (2009). Emotional intelligence of Malaysian academia towards work performance. International Education Studies, 2, 103-112.

xxxv. Salovey, P. (2001). Applied emotional intelligence: regulating emotions to become healthy, wealthy, and wise. Emotional intelligence and Everyday Life, 168-184.

xxxvi. Sarwar, S., \& Abugre, J. (2013). The Influence of Rewards and Job Satisfaction on Employees in the Service.

xxxvii. Schuetz, H. (2011). Acquiring social skills-the key to professional success.

xxxviii. Schunk, D. H., Zimmerman, B. J. 2003. Self-regulation and Learning. In: Reynolds, W. M., \& Miller, I. B. (Ed), Handbook of Psychology, 59-78. New Jersey, N: John Wiley \& Sons. Inc.

xxxix. Scullen, S. E., Mount, M. K., Goff, M. (2000). Understanding the latent structure of job performance ratings. Journal of Applied Psychology, 85(6), 956-970.

xl. Seibert, S.E., Kraimer, M.L., Liden, R.C. (2001). A social capital theory of career success. Academy of Management Journal, 44, 219-237.

xli. Shooshtarian, Z., Ameli, F., \& Aminilari, M. (2013). The effect of labor's emotional intelligence on their job satisfaction, job performance, and job commitment. Iranian Journal of Management Studies, 6(1), 27-43.

xlii. Siniscalco, M.R., Auriat, N. and Kenneth, N.R. (2005). Quantitative research methods in educational planning: UNESCO International Institute for Educational Planning. Retrieved from, http:/ / www.unesco.org/iiep/ PDF/ TR Mods/ Qu Mod8.pdfretrieved

xliii. Skaalvik, E. M, Skaalvik, S. (2007). Dimensions of teacher self-efficacy and relations with strain factors, perceived collective teacher efficacy, and teacher burnout. Journal of Educational Psychology, 99 611-625.

xliv. Sutton, R. E. (2004). Emotional regulation goals and strategies of teachers. Social Psychology of Education, 7,379398

xlv. Tseng, S. M., \& Huang, J. S. (2011). The correlation between wikipedia and knowledge sharing on job performance. Expert Systems with Applications, 38, 6118-6124.

xlvi. Welch, B. L. (1947). The generalization of Student's problem when several different population variances are involved. Biometrika, 34 (1-2), 28-35.

xlvii. Wolmarans, S. Martins, N. (2001). The 360-degree emotional competency profiler. Unpublished manual. Johannesburg: organizational diagnostics and learning link international

xlviii. Yeung, R. (2009). Emotional intelligence, the new rules. Benin city: Beulah Land Publications.

\section{Appendix}

The Questionnaire

This questionnaire has two parts; you are kindly requested to fill in all the sections taking into account the instructions given. The information provided will be treated with confidentiality.

Part I.

The purpose of this section is to request you to honestly provide the information that applies to you. Please tick $(\sqrt{ })$ in the box according to the scale: 0 (Never) 1 (Rarely) 2 (Sometimes) 3 (Often) 4 (Always) 


\begin{tabular}{|c|c|c|c|c|c|c|}
\hline \multicolumn{2}{|r|}{ Self - Awareness } & $\mathbf{0}$ & 1 & 2 & 3 & 4 \\
\hline 1 & My feelings are clear to me at any given moment & & & & & \\
\hline 2 & Emotions play an important part in my life & & & & & \\
\hline 3 & My moods impact the people around me & & & & & \\
\hline 4 & I find it easy to put words to my feelings & & & & & \\
\hline 5 & My moods are easily affected by external events & & & & & \\
\hline 6 & I can easily sense when I am going to be angry & & & & & \\
\hline 7 & I readily tell others my true feelings & & & & & \\
\hline 8 & I find it easy to describe my feelings & & & & & \\
\hline 9 & Even when I am upset, I'm aware of what's happening to me & & & & & \\
\hline 10 & $\begin{array}{l}\text { I am able to stand apart from my thoughts and feelings and examine } \\
\text { them }\end{array}$ & & & & & \\
\hline & EMOTIONAL MANAGEMENT & 0 & 1 & 2 & 3 & 4 \\
\hline 1 & I accept responsibility for my actions & & & & & \\
\hline 2 & I find it easy to make goals and stick with them & & & & & \\
\hline 3 & I am an emotionally balanced person & & & & & \\
\hline 4 & I am a very patient person & & & & & \\
\hline 5 & I can accept critical comments from others without becoming angry & & & & & \\
\hline 6 & I maintain my composure, even during stressful times & & & & & \\
\hline 7 & If an issue does not affect me directly, I don't let it bother me & & & & & \\
\hline 8 & I can restrain myself when I eel anger towards someone & & & & & \\
\hline 9 & I control urges to overindulge in things that could damage my well being & & & & & \\
\hline 10 & I direct my energy into creative work or hobbies & & & & & \\
\hline & SOCIAL EMOTIONAL AWARENESS & 0 & 1 & 2 & 3 & 4 \\
\hline 1 & I consider the impact of my decisions on other people & & & & & \\
\hline 2 & I can easily tell if the people around me are becoming annoyed & & & & & \\
\hline 3 & I can sense it when a person's mood changes & & & & & \\
\hline 4 & I am able to be supportive when giving bad news to others & & & & & \\
\hline 5 & I am generally able to understand the way other people feel & & & & & \\
\hline 6 & My friends can tell me intimate things about themselves & & & & & \\
\hline 7 & It genuinely bothers me to see other people suffer & & & & & \\
\hline 8 & I usually know when to speak and when to be silent & & & & & \\
\hline 9 & I care what happens to other people & & & & & \\
\hline 10 & I understand when other people's plan changes & & & & & \\
\hline & RELATIONSHIP AWARENESS & 0 & 1 & 2 & 3 & 4 \\
\hline 1 & I am able to show affection & & & & & \\
\hline 2 & My relationships are safe places for me & & & & & \\
\hline 3 & I find it easy to share my deep feelings with others & & & & & \\
\hline 4 & I am good at motivating others & & & & & \\
\hline 5 & I am a fairly cheerful person & & & & & \\
\hline 6 & It is easy for me to make friends & & & & & \\
\hline 7 & People tell me I am sociable and fun & & & & & \\
\hline 8 & I like helping people & & & & & \\
\hline 9 & Others can depend on me & & & & & \\
\hline 10 & I am able to talk someone down if they are very upset & & & & & \\
\hline
\end{tabular}

Part $2(\mathrm{~A})$ Table 8

Please indicate with a tick $(\sqrt{ })$ your age bracketand your teaching experience in years in the appropriate boxes.

\begin{tabular}{|c|c|c|c|}
\hline Age (years) & Tick $(\sqrt{ })$ & Length of service (years) & Tick $(\sqrt{ })$ \\
\hline Under 26 & & Under 6 & \\
\hline $26-29$ & & $6-9$ & \\
\hline $30-34$ & & $10-14$ & \\
\hline $35-39$ & & $15-19$ & \\
\hline $40-44$ & & $20-24$ & \\
\hline $45-49$ & & $25-29$ & \\
\hline Above 49 & & Above 29 & \\
\hline
\end{tabular}

Table 9 
Part 2 (B)

\begin{tabular}{|c|c|c|c|c|c|c|}
\hline \multicolumn{2}{|r|}{ JOB PERFORMANCE $\{$ TOTAL = } & 0 & 1 & 2 & 3 & 4 \\
\hline 1 & $\begin{array}{l}\text { I help other employees with their work when they } \\
\text { have been absent. }\end{array}$ & & & & & \\
\hline 2 & I achieve the objectives of my job. & & & & & \\
\hline 3 & $\begin{array}{c}\text { I volunteer to do things not formally required by } \\
\text { the job. }\end{array}$ & & & & & \\
\hline 4 & I meet the criteria for performance. & & & & & \\
\hline 5 & $\begin{array}{c}\text { I take initiatives to orient new employees to the } \\
\text { department even though not part of my job } \\
\text { description. }\end{array}$ & & & & & \\
\hline 6 & I demonstrate expertise in all job-related tasks. & & & & & \\
\hline 7 & $\begin{array}{l}\text { I help others when their work load increases } \\
\text { (assists others until they get over the hurdles). }\end{array}$ & & & & & \\
\hline 8 & I fulfil all the requirements of the job. & & & & & \\
\hline 9 & I assist my colleagues with their duties. & & & & & \\
\hline 10 & $\begin{array}{c}\text { I can manage more responsibility than typically } \\
\text { assigned. }\end{array}$ & & & & & \\
\hline 11 & $\begin{array}{l}\text { I make innovative suggestions to improve the } \\
\text { overall quality of the department. }\end{array}$ & & & & & \\
\hline 12 & I appear suitable for a higher-level role. & & & & & \\
\hline 13 & $\begin{array}{l}\text { I willingly attend functions not required by the } \\
\text { organization but helps in its overall image. }\end{array}$ & & & & & \\
\hline 14 & $\begin{array}{l}\text { I am competent in all areas of the job, handle } \\
\text { tasks with proficiency. }\end{array}$ & & & & & \\
\hline 15 & $\begin{array}{l}\text { I perform well in the overall job by carrying out } \\
\text { tasks as expected. }\end{array}$ & & & & & \\
\hline 16 & $\begin{array}{l}\text { I plan and organize to achieve objectives of the } \\
\text { job and meet deadlines. }\end{array}$ & & & & & \\
\hline
\end{tabular}

Table 10 